\title{
The influence of waters environment on the existence of Martapura port in Banjarmasin, South Kalimantan
}

\author{
Endang Susilowati* \\ Department of History, Faculty of Humanities, Diponegoro University, Semarang 50275, Indonesia
}

\begin{abstract}
This article examines the influence of waters environment on the existence of Martapura port in Banjarmasin, South Kalimantan. Martapura port is a port located on the banks of Martapura River, Banjarmasin. This port has been an essential trade center since the 17th century during the heyday of Banjar sultanate. The strategic port location along the riverbank that divides Banjarmasin makes Martapura port crowded and visited by sailors and traders from various islands and other regions in Indonesia, even from other countries. Through historical research methods consisting of heuristics, source criticism, interpretation, and historiography, this article reveals how the waters environment influenced the existence of Martapura port until finally the port had to be moved to a new location. The results emphasize that the narrowing Martapura river due to the development of economic centers and residential settlements in the form of floating houses on both sides of the river and also sedimentation in the estuary, caused disruption of the shipping lanes to the port and the silting of the turning basins. As a result, the waterway became narrow and large ships were no longer able to move into the port. Therefore, in 1961, the construction of a new port on the banks of Barito river began and since 1965 Martapura port has only been used for the activities of small wooden ships and sailboats.
\end{abstract}

Keywords: Martapura port; Banjarmasin; Martapura river; Barito river; waters environment; sedimentation; floating houses.

\section{Introduction}

Martapura port, also known as Banjarmasin port, is one of the most essential ports in South Kalimantan. This port is located in Banjarmasin, on the western side of Martapura river. Since the 16th century, Banjarmasin under Banjar Sultanate has become an important center of pepper trade on the coast of southern Kalimantan for the international market [1]. From traditional sources, it was known that various forest products and mining products

\footnotetext{
*Corresponding author : endangsusilowati@,lecturer.undip.ac.id
} 
from South Kalimantan such as pepper, wood, rattan, resin, wax, eucalyptus, reptile skin, diamonds, and gold had been traded in interisland and international trade networks [2]. Until the mid-20th century, in these trade commodities, except for pepper no longer in production, it was added to the handicraft products of the inland residents transported to the trade center in Banjarmasin via river transportation and subsequently brought to various regions or other countries by merchant ships through Martapura port.

Banjarmasin is known as a river city due to a number of rivers flowing in this port city. The largest river is Barito river which has many distributaries and tributaries. At the end of the 19th century, more than 45 rivers emptied into Barito river and no less than 148 villages were built along the left and right sides of this river and its distributaries [3]. Martapura River is one of the distributaries of Barito river which flows through Banjarmasin. Along with the city development and the economic activities of its inhabitants, residential settlements and economic centers such as markets and shops have been developed on both sides of Martapura watershed [4]. It was indeed inseparable from the existence of Martapura port as a center for the transportation of goods and passengers. There was clearly a positive correlation between port development and growth of economic centers and human settlements. However, because the port location was in the watershed and protruded into the city, the growth of settlements on both sides of the river brought unfavorable consequences for the waters environment around the port. Since the Dutch colonial era, the poor waters environment around the port had become a problem disrupting the smoothness of port shipping lanes. The continued sedimentation in Barito river as the port entrance and the increasingly narrowing port shipping lanes prompted the Dutch colonial government to begin conducting research to explore port shipping lanes and new port locations. In 1847, a research team was formed by the government to examine the possibility of shipping for large ships in Barito watershed to upstream [5]. It also investigated several locations that made it possible to move ports. Nonetheless, until 1915, the plan to move the port could not be realized since it was hampered by the high cost [6]. In 1955, another research was conducted and three prospective new port locations were obtained, namely Laut Island, Kotabaru, and Batulicin. Nevertheless, in the end, the new port location was set on the banks of Barito river, that was not too far from the downtown. The new port began the construction in 1961 and was completed in 1965 [7]. Since then, the function and existence of Martapura port had increasingly declined, until finally it was only used for the activities of wooden vessels with dead weights under 500 tons and inter-island sailboats.

Based on the background that has been explained, this article discusses two main things, namely the waters environment around Martapura port and the influence of the deteriorating waters environment on the existence of the port.

\section{Method}

The historical method used in this article; the process of critically examination and analyzing past records and relics [8]. The historical method consists of four stages. The first stage is heuristic or source collection, both primary and secondary sources. Primary sources obtained through archival studies at National Archives of the Republic of Indonesia, Jakarta, and Lambung Mangkurat Museum Banjarbaru, South Kalimantan; while secondary sources obtained through library research on literature or scientific papers that relevant to the problem being discussed. The second stage is source criticism consisting of external criticism to obtain source authenticity and internal criticism to obtain source credibility. The third stage is interpretation of historical facts. At this stage, the collected data are analyzed and concluded. The fourth stage is historiography or historical writing; an attempt to imaginatively reconstruct past events based on historical facts [9]. 


\section{Results and discussion}

This section discusses the geographical location of Martapura port, the waters environmental conditions around the port, and the influence of the waters environmental conditions of the port on the existence of Martapura port. The geographical conditions of the port need to be explained since it is closely related to the waters environmental conditions around the port and the shipping lanes into and out of the port.

\subsection{Geographical Conditions of Martapura Port}

Martapura port in Banjarmasin is one of the main ports and a gateway for South Kalimantan region. Since the beginning of the 19th century, precisely since 1825 , Martapura port has been designated as one of the free ports [10]. It means that Martapura port may be visited by ships from various regions/other countries. Judging from its location, Martapura port is a deep port, a port not located on the coast. The position of Martapura port is on the west bank of Martapura river, a tributary of Barito river. Barito River is a large river with a number of tributaries and a port entrance. Martapura River flows on the left side of Barito river, approximately 20 kilometers from the coast, where Barito river empties [11]. The confluence of the two rivers creates a meander that causes a narrowing of water along approximately nine kilometers. Along the meander, large ships with dead weights above 1000 tons must sail one by one [12].

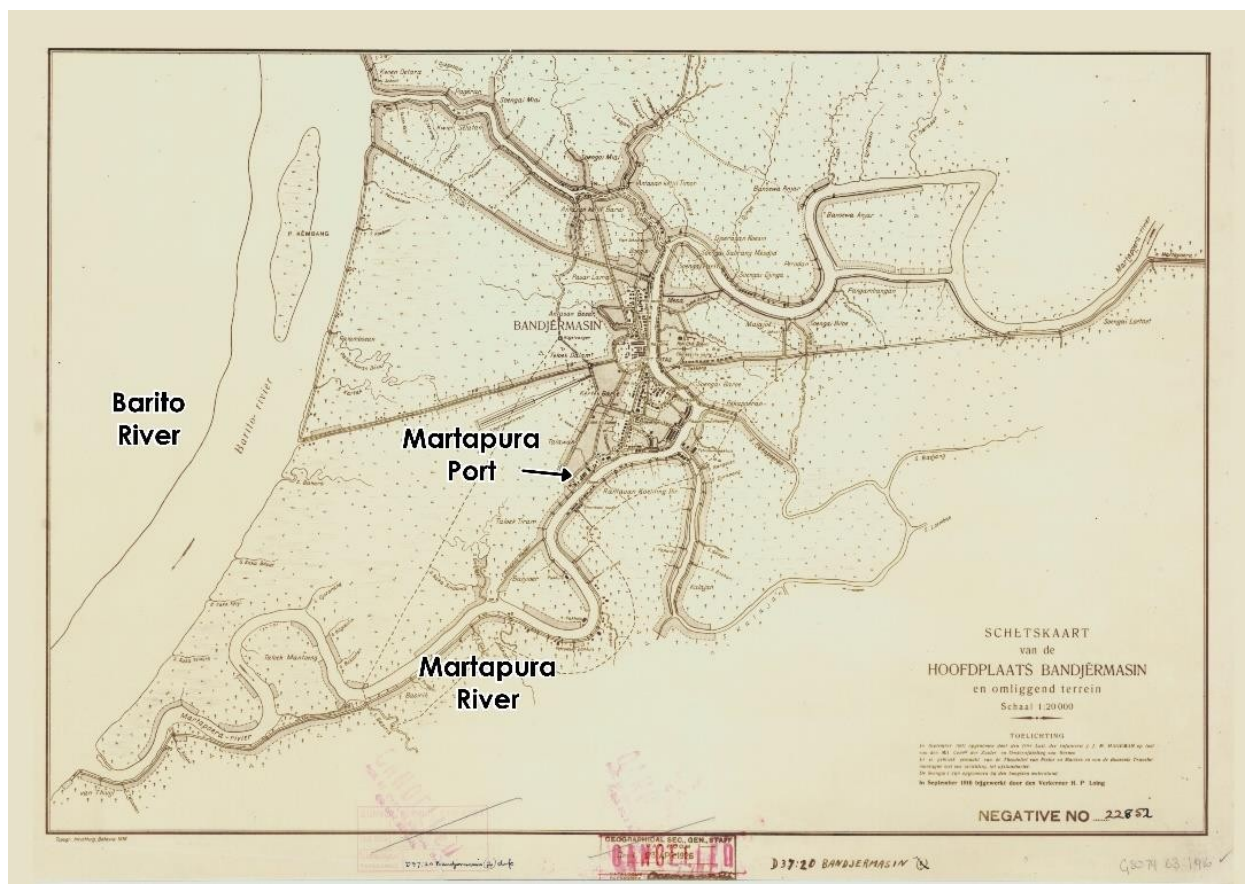

Fig. 1. Map of Martapura port location on the west side of Martapura watershed, 1916 (Processed from https://id.wikipedia.org/wiki/Berkas:Peta Banjarmasin 1916.jpg) 
From the map in Figure 1, it can be seen that at the beginning of the 20th century, the shipping lanes from the estuary of Martapura river to the port in Banjarmasin had to go through winding and long waterway. To reach Martapura port, it took about 3 hours of voyage from the coast, that was 2 hours of voyage on Barito river of which the width was between 800-900 meters with a depth of about 9-10 meters, and 1 hour of voyage on Martapura river which had a depth of 4-5 meters with a width between 85-95 meters [13].

Judging from the shipping lanes, Martapura port was a tidal port where the smoothness of shipping lanes into and out of the port was very dependent on the arrival of the tide. This was due to the existence of a delta formed from siltation, both from rivers flowing into Barito river or from the sea carried by the current at high tide [14]. Hence, at low tide, large ships could not enter or exit Barito river. After successfully passing Barito estuary, ships could navigate Barito river without difficulty, even though then they would have to move into the narrow and winding Martapura waterway to get to the port.

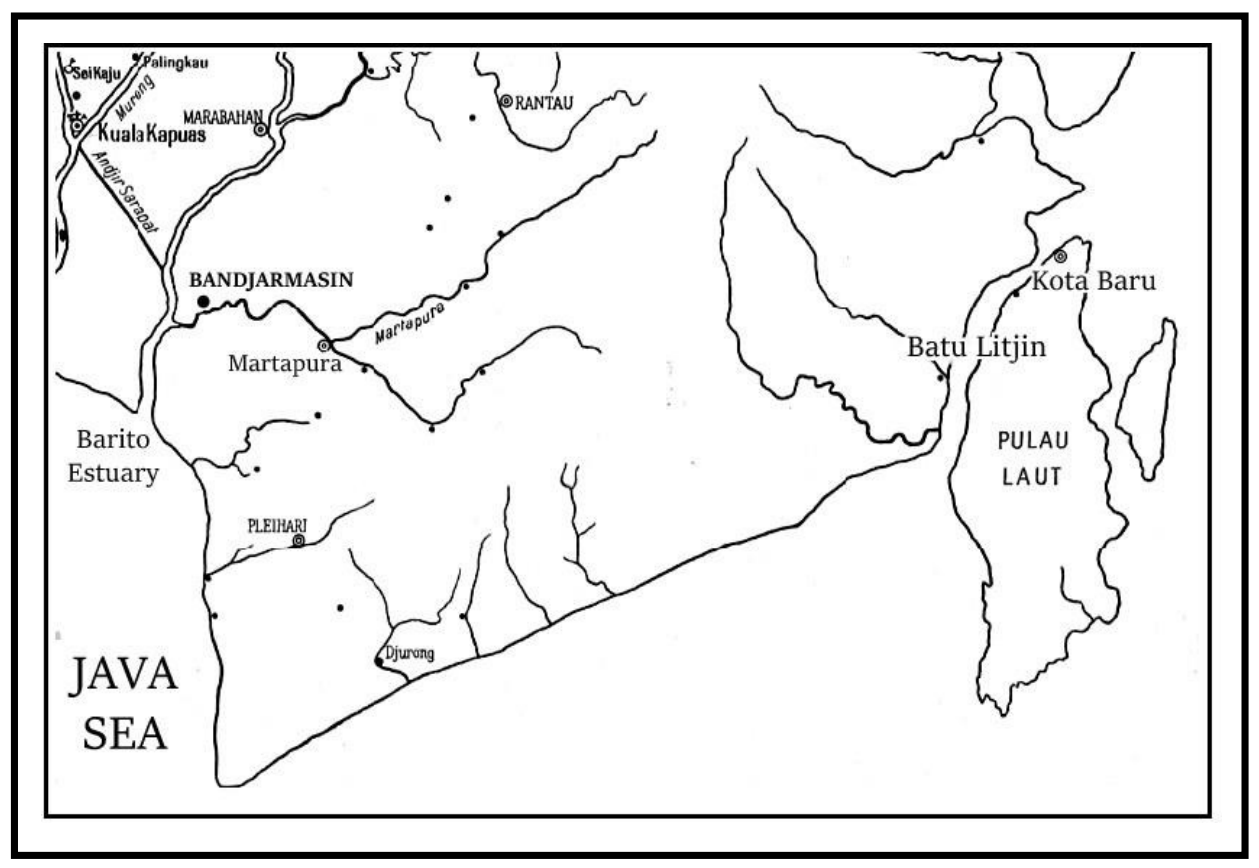

Fig. 2. Barito estuary in Java Sea which is an entrance to Martapura port (Processed from http://www.bmarchives.org/items/show/100202735)

\subsection{Waters Environmental Conditions around Martapura Port}

\subsubsection{City development}

Since 1860, Dutch had abolished Banjar sultanate so that some family members of Banjar sultanate had to step away to the inland and continued the resistance from their territories in the inland. Banjar Sultanate was conquered by Dutch in 1863, after fierce resistance from Banjar sultans since 1859 . The resistance of Banjar sultanate family only really stopped in 1906 after the last sultan, Sultan Muhammad Seman, died in $1905[15,16]$.

Dutch strengthened its position in Banjarmasin and rebuilt the port located on Martapura river in 1900. Along with the strengthening of Dutch political and economic power in South Kalimantan, Banjarmasin began to develop. The center of European 
settlement in a delta named Tatas became the forerunner to the center of Banjarmasin. Various ethnics and tribes came and went to trade and even settled along Barito and Martapura rivers. Bugis, Makassar, Javanese, Madurese, Chinese, and European traders became inseparable parts of the development of Banjarmasin [17]. Some of these migrants even built settlements in Banjarmasin, on the riverbanks. On both sides of Martapura river passing through the downtown, it began to be crowded with settlements of local residents and migrants, shop buildings, and trading offices owned by Dutch and Chinese.

In 1912, Banjarmasin was designated as the residency capital of South and East Kalimantan (Zuider-en Oosterafdeeling van Borneo) and in 1938 the autonomy status of Banjarmasin was upgraded to gemeente (municipality) [18]. Subsequently, Banjarmasin became a crowded and bustling city with a center for economic activities especially in Barito and Martapura rivers. Between the two major river flows, Martapura port was developed into a transit and export import port. The development of Martapura port correlated with the development of Banjarmasin, and vice versa. Nonetheless, the physical development of Banjarmasin which tended to get closer to the port and occupied parts of the riverbanks over a long period of time disrupted the port activities.

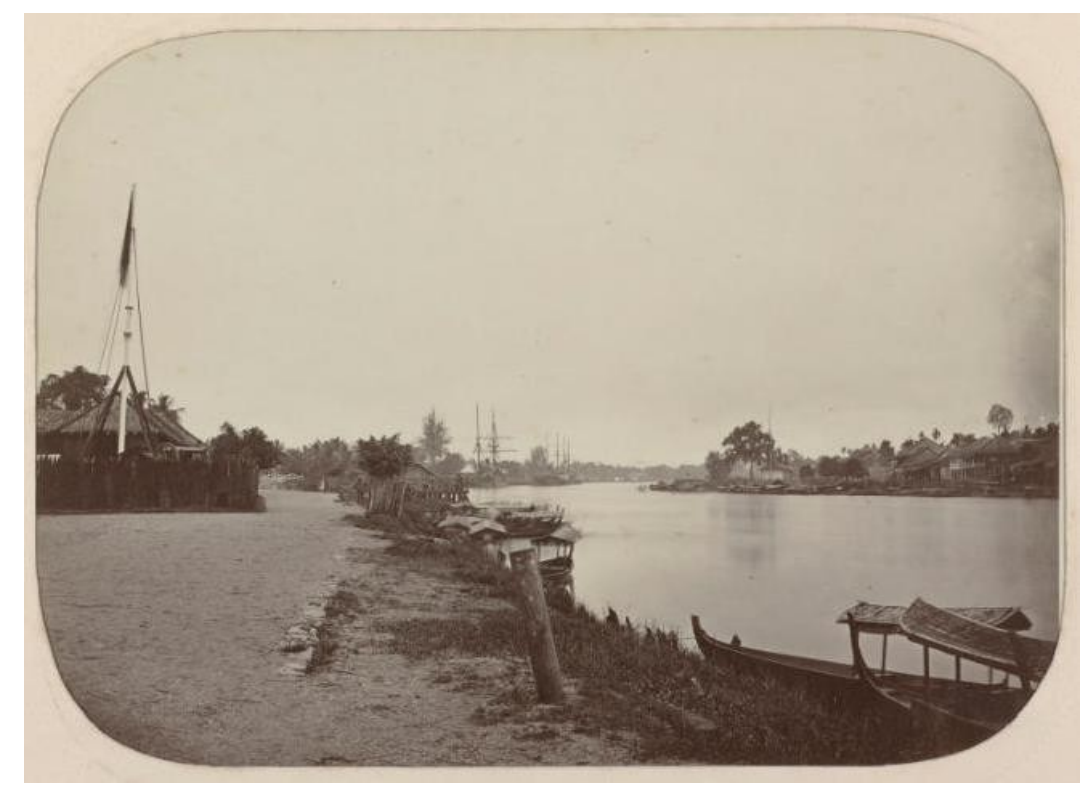

Fig. 3. Delta Tatas with Dutch checkpoint on the left and Martapura port appearing in the distance, in 1875 (Collection of Museum Volkenkude, Leiden) 


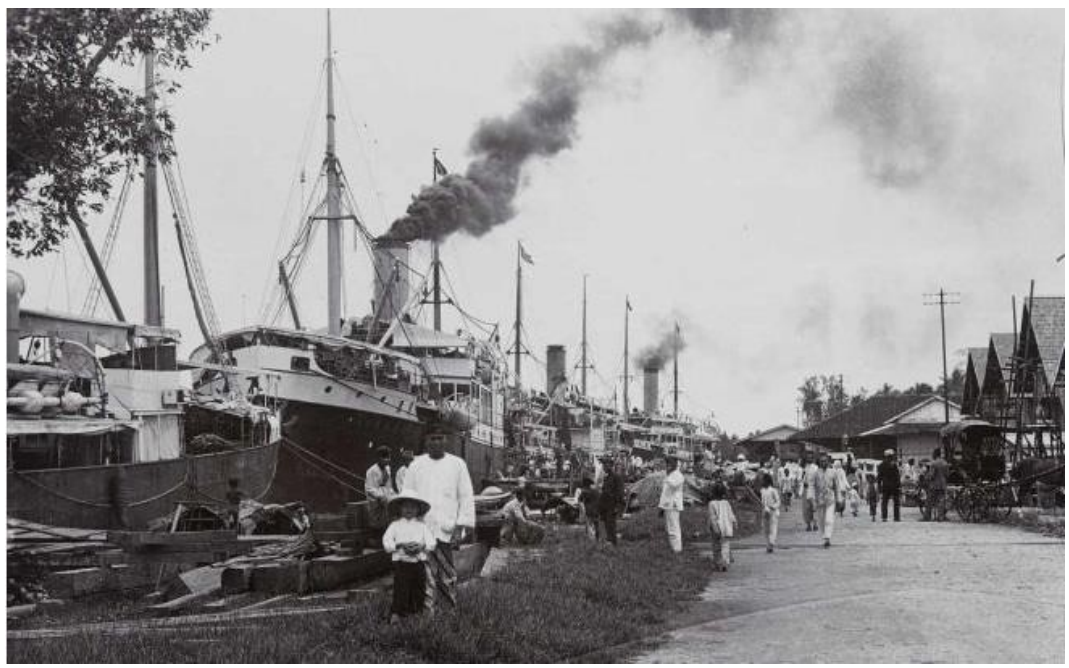

Fig. 4. Bustle at Martapura port with steamships anchored at the beginning of the 20th century (Collection of Tropenmuseum, Amsterdam)

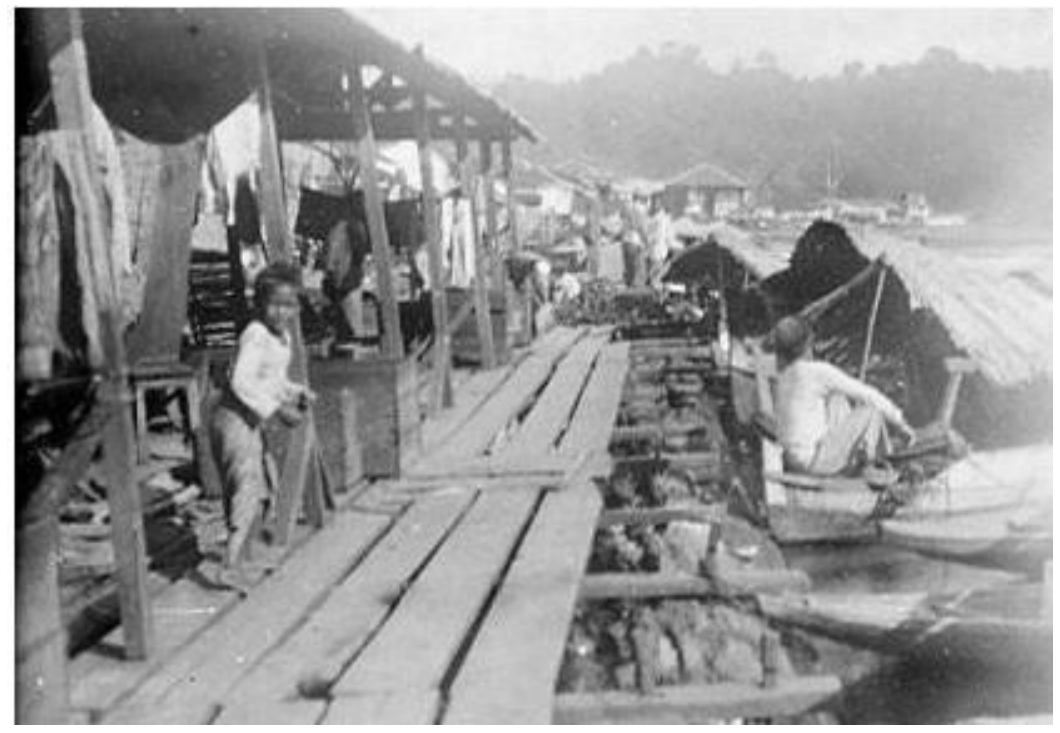

Fig. 5. Market on Martapura riverbanks (Collection of Prentenkabinet Universiteit Leiden) 


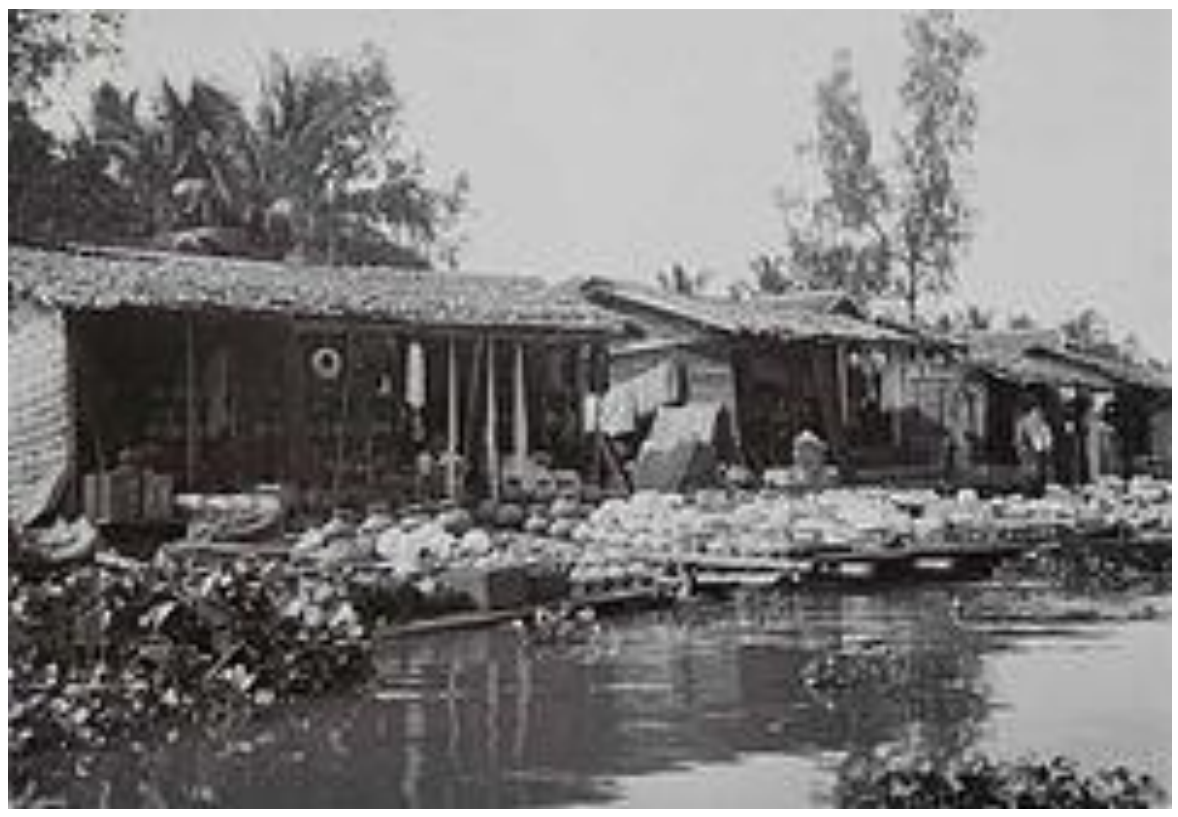

Figure 6. Floating shops on Martapura watershed (Collection of Tropenmuseum, Amsterdam)

\subsubsection{Waters environment}

Martapura port is surrounded by three interconnected large rivers, namely Barito river, Martapura river, and Kuin river. The last two rivers are the distributaries which empty into Barito river. Kuin River connects Barito river with Martapura river. The meeting of the three rivers forms a triangle that surrounds Banjarmasin. In connection with Martapura port, the three river areas constitute the environment of the port interests. 


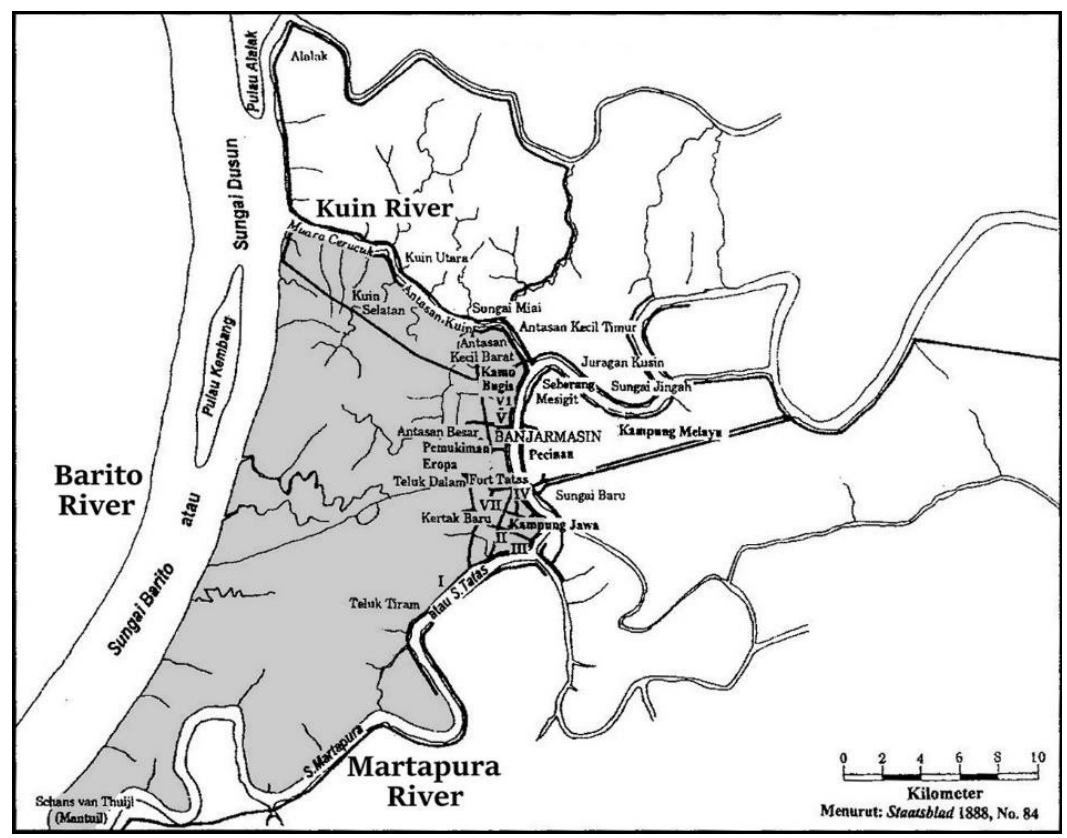

Fig. 7. Waters environment around Martapura port formed by the meeting of Barito, Martapura, and Kuin rivers (Processed from H. Sjamsuddin, Pegustian dan Tumenggung)

Barito River which empties into Java Sea is the entrance to Martapura port. In the 20th century, the width of the waterway varied from 300 to 900 meters and the width of the estuary was about 2 kilometers, with an average depth of 7-8 meters [19]. The more it got to the upstream, the narrower Barito river flowed. Along Barito river flows, there were several small islands, including Kembang, so it looked like that Barito river was split in two. Barito river flows did not always flew in the same direction within 24 hours. When the sea water rose and moved into Barito estuary, the river water level rose and flew upstream, on the contrary when the sea water receded, the river water level dropped and the water flew downstream [20]. When the water level of Barito river rose, ships could move into the estuary and sailed to the port. In contrast, when the water receded, the ships could not pass Barito estuary since the water level was in the lowest condition. Entering the mid-20th century, wood processing factory buildings began to develop on Barito riverbanks along the side Banjarmasin. 


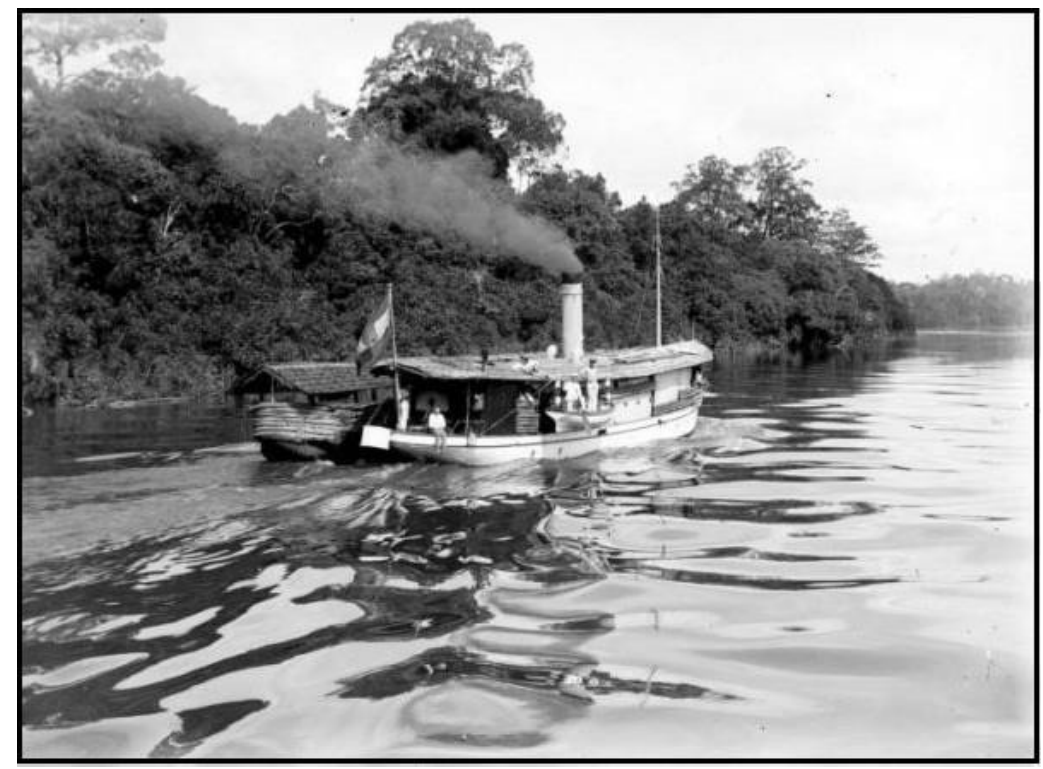

Fig. 8. A steamship on Barito riverbanks, 1920 (geheugen.delpher.nl)

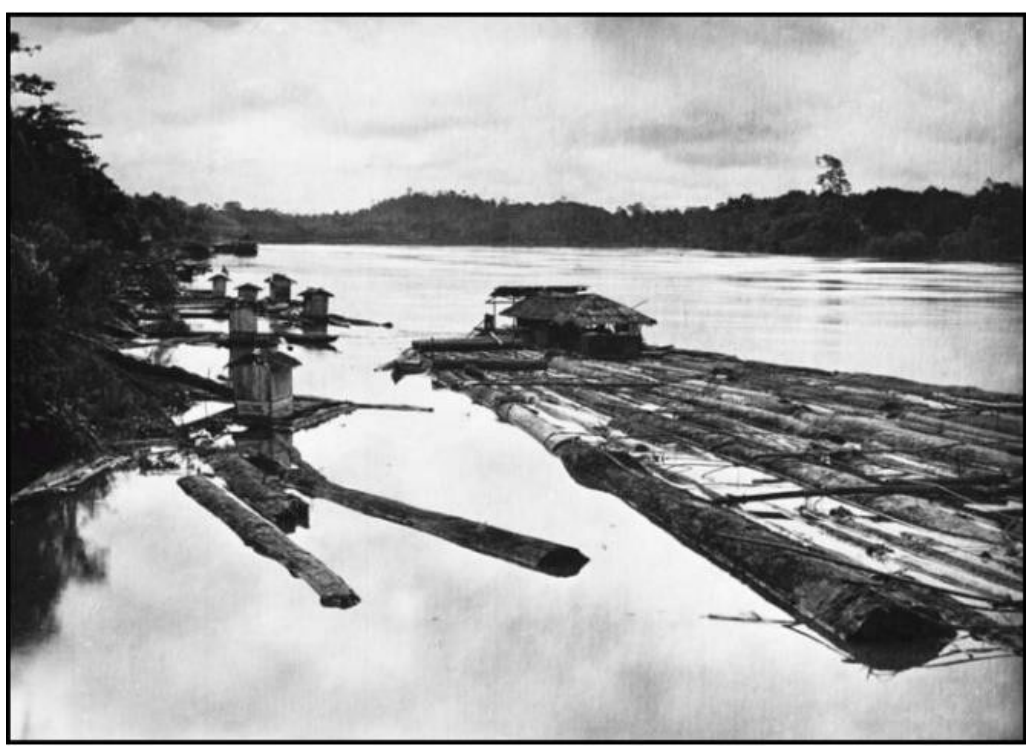

Fig. 9. Wood processing factories on Barito riverbanks, 1952 (Source: Collection of Tropenmuseum, Amsterdam)

Martapura river is one of Barito tributaries. This river flows on the left side of Barito river and can be navigated along approximately 30 nautical miles to Martapura. From Martapura estuary on Barito river, the waterway divides Banjarmasin and continues upstream to Martapura. Since the time of Vereningde Oost-Indische Compagnië (VOC), both Martapura riverbanks close to Banjarmasin area have been filled with residential areas and their various socioeconomic activities. There are Banjar villages, Bugis villages, Javanese villages, Chinese villages, and others. The villages, according to their names, are inhabited by traders or migrants from these ethnic groups. Europeans live in the center of Banjarmasin, separated from local residents and immigrants from various ethnicities. 
Meanwhile, Kuin River is one of the rivers that connects the inland areas with Banjarmasin. Many economic activities of inland residents were carried out on this river. In the morning, in Kuin river, there were transactions of various kinds of agricultural products and goods needed by the residents along the river flows. The floating market activities began from dawn until sunrise.

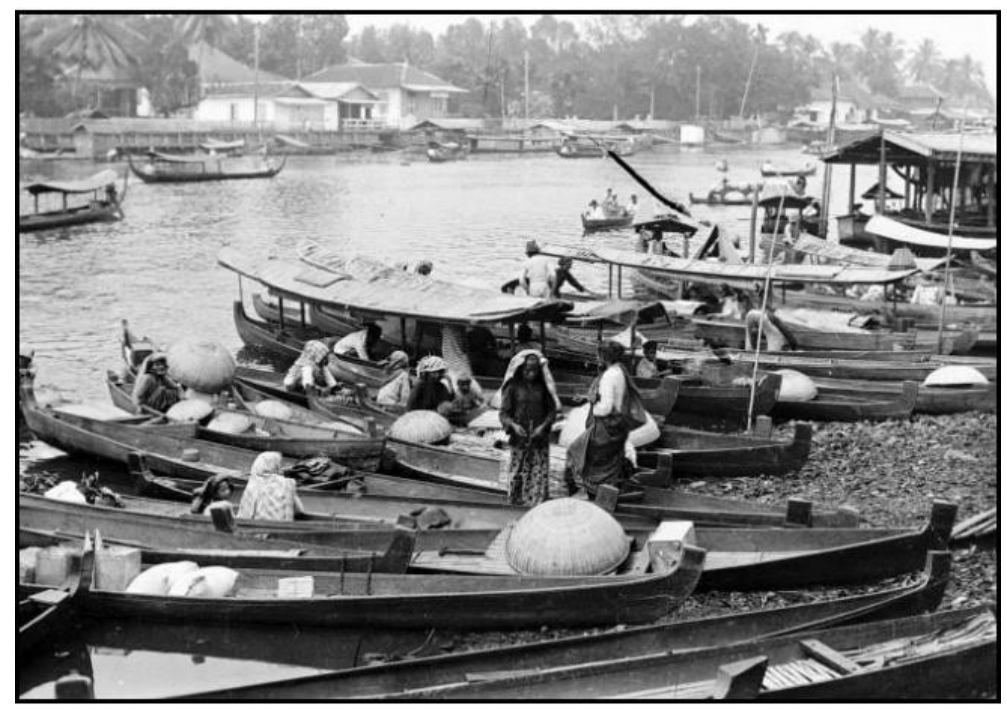

Fig. 10. Economic activities of residents in Martapura river (Collection of Tropenmuseum, Amsterdam)

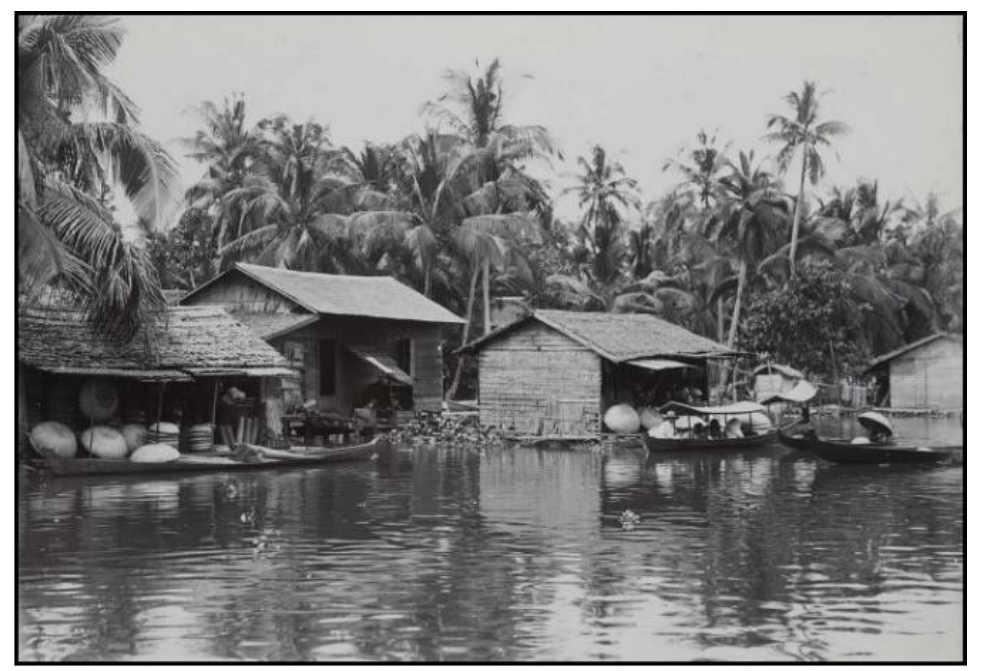

Fig. 11. Floating shops in Kuin riverbanks (Collection of Tropenmuseum, Amsterdam)

In addition to being centers of economic activities, Martapura river and Kuin river were also the location of residential settlements, both local residents and migrants. Banjar tribe used to build lanting houses (floating houses) on the riverbanks, an established culture that has been passed down through Banjar community. From Valentijn's travel logs, it is known that since the 17th century, houses with bamboo or wooden walls built on water has been found on the riverbanks in Banjarmasin [21]. In the 1960s, on the two Martapura riverbanks 
there were still hundreds of lanting houses. The existence of lanting houses caused Martapura river flows to narrow, making it difficult for large ships to move into Martapura port.

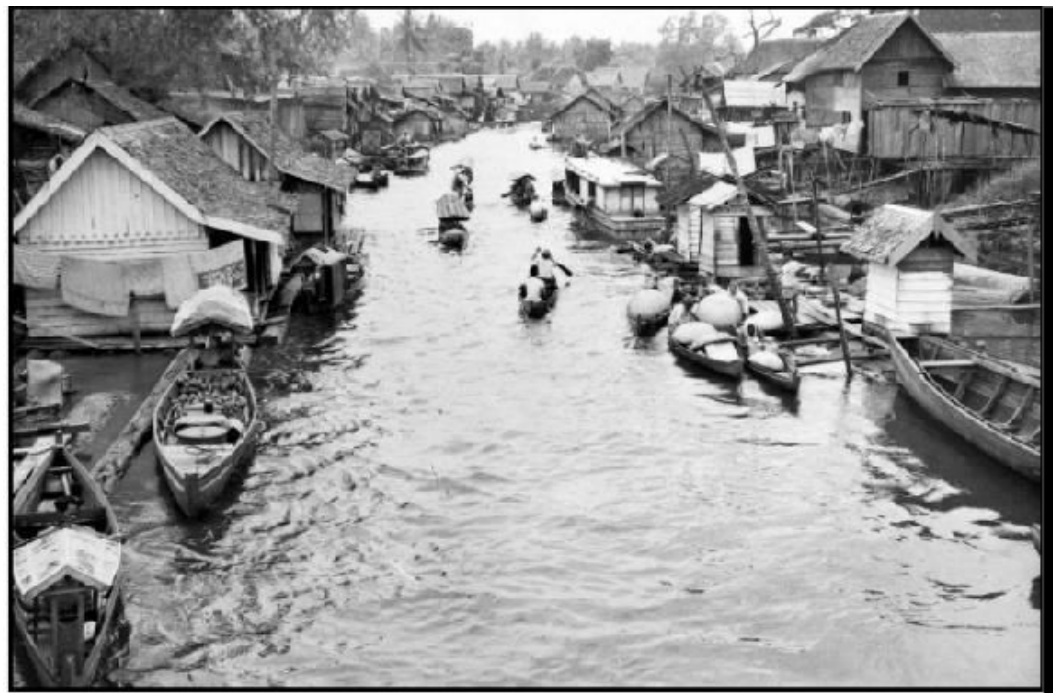

Fig. 12. Crowd of water traffic and floating houses on Martapura tributaries (Collection of Tropenmuseum, Amsterdam)

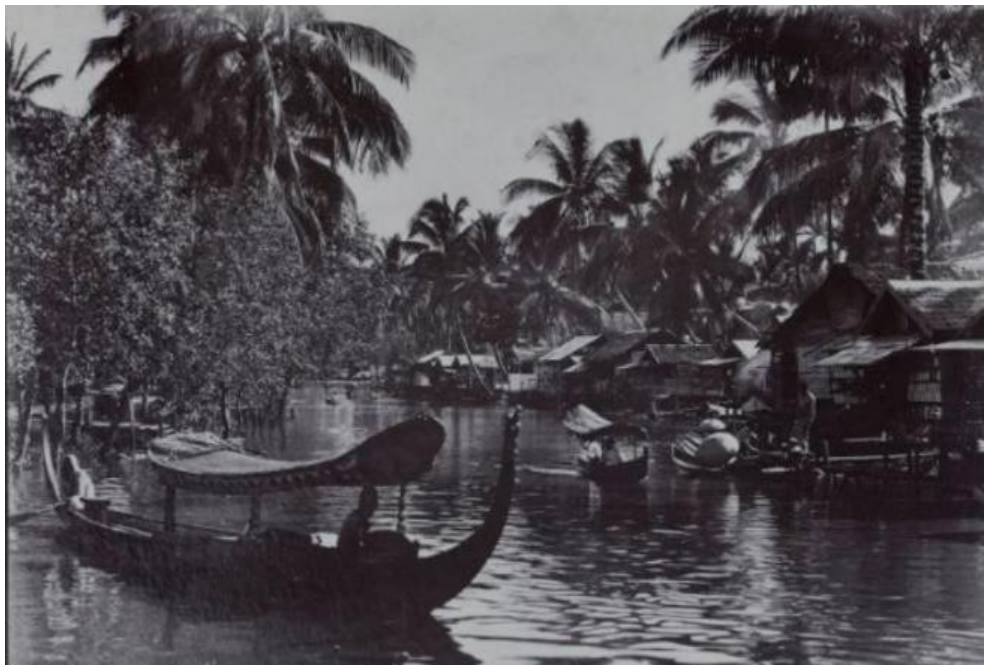

Fig. 13. Shipping lanes on Martapura river full of lanting houses (Collection of Volkenkunde Museum, Leiden)

\subsection{Influence of Waters Environment on the Port Existence}

Naturally, Martapura port has advantages and disadvantages since it is located on the riverbanks far from the high seas. The advantages, among others, are very safe for anchored ships because they are protected from strong wind blows and large waves. Moreover, transportation of forest products, agricultural products, and mining products from the buffer zones in the inland to the port and distribution of goods from the port to the inland are 
guaranteed to be smooth because the existing river networks facilitate the mobility of goods and people. River civilization has become an inseparable part of the population of Banjarmasin and South Kalimantan in general. Various aspects of people's lives, whether economic, social or cultural aspects, cannot be separated from rivers or river networks. When the settlement centers are still around the estuaries and tributaries, their daily activities relatively do not disturb the shipping lanes to or from the port. Nevertheless, along with the population growth and development of settlements along Martapura riverbanks and other rivers in the port environment, the smoothness of shipping lanes into or out of the port has been disrupted.

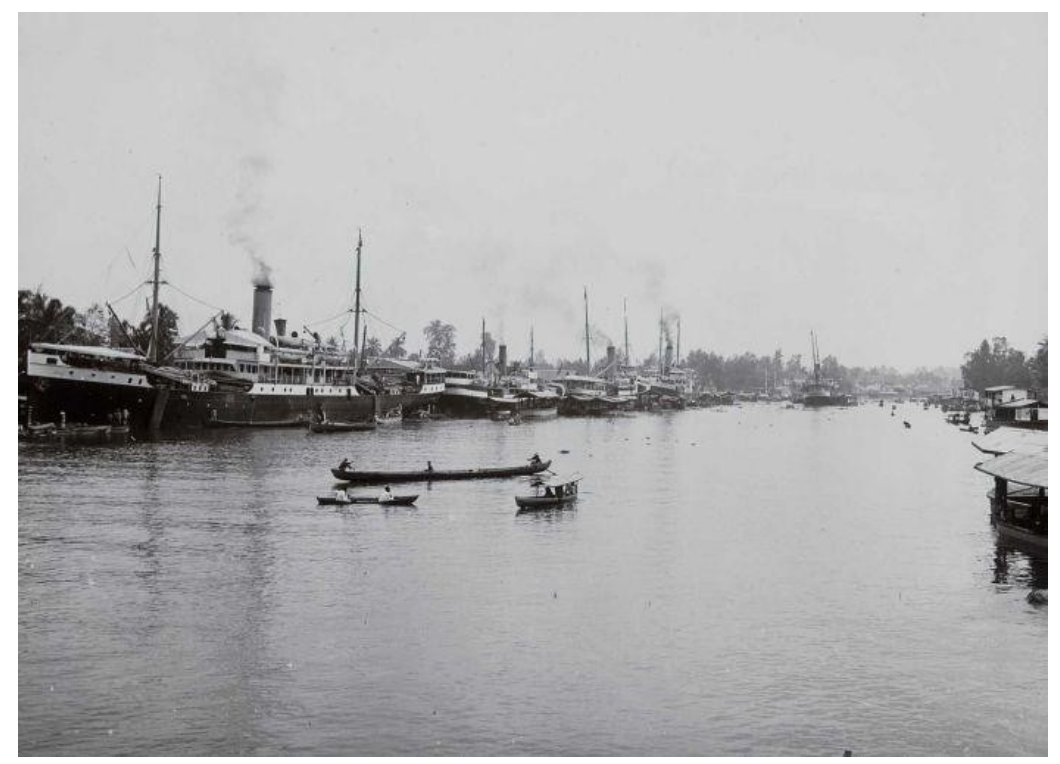

Source: Collection of Tropenmuseum, Amsterdam.

Fig. 14. Steamships and wooden ships anchored along Martapura port in the 20th century.

The disadvantages of Banjarmasin port are caused by two factors, namely natural factors and human factors (related to the culture of settlement and the daily activities of residents in the waters environment surrounding the port). The disadvantages caused by natural factors are mainly related to siltation at Barito estuary, due to high sedimentation and formation of deltas at Barito estuary. The silt at Barito estuary over a long period of time has formed a delta at the entrance to Barito waterway to Martapura port. At low tide, Barito estuary cannot be navigated because the water depth is less than two meters [22]. Consequently, ships that will enter or exit the port must wait for the tide. At that time, the depth of the water in Barito estuary reached 4-5 meters, making it safe to navigate. To avoid the ship being trapped and stranded at Barito estuary, the port managers made a tidal schedule that must be obeyed by the ships' masters who would pass Barito estuary.

The silting of estuaries and turning basins is a problem faced continuously by Martapura port. A number of tributaries that flow into Barito and Martapura rivers cause siltation in the port waters environment as if it is not handled yet. The efforts to remove the silt with a very high cost continue to be done regularly, but it will not be able to eliminate this weakness point of the port.

Meanwhile, community cultural factors also become a problem for the smoothness of activities of Martapura port. The daily activities of residents who live along Martapura riverbanks around the port and downtown and their lanting houses which always move are 
other problems for Martapura port. The existence of growing residential settlements on both banks of Martapura river and other rivers in the port waters environment, such as Kuin river and Alalak river, has caused the shipping lanes from Martapura estuary to the port becomes narrow. Sometimes, the residential lanting houses are hit by the sailing ships. The houses tied to the raft or tethered to the stake move due to the river currents and the blowing wind. The narrow paths in several meanders along with houses on both banks make it difficult for ships to move, especially if they happen to run into other ships. In such conditions, it often happens that houses have been hit by the ships.

Another thing that becomes a problem for the shipping on Martapura river is the daily activities of residents who live on the river. Since they live in the waters, most of their activities utilize river flows. For them, the river is no different from the road. They do their daily activities with small boats called jukung sudur and klothok. Almost every family has a boat as a means of transportation. In the morning until evening, most of the residents work as fishermen and traders on their boats in Martapura, Kuin, Alalak, and other river flows. Their daily activities add the dense traffic in a fairly extensive port waters environment.

Natural factors and cultural factors that constrain the development of Martapura port as described above has been going on since the colonial times, maybe even before. During Dutch colonial era, several canals were made to reduce the difficulty of shipping on Martapura river, caused by very long and winding waterway, and increasingly crowded residential settlements. In 1960, another canal was made to connect Barito River and Martapura River. The canal, in Banjar language known as antasan, was named Bromo and could shorten the shipping distance from Barito river to Martapura port by 30 minutes, so the shipping time originally 2 hours became only 1.5 hours [23].

In addition to making several antasan, since the mid-19th century, Dutch government had explored the possibility of moving the port to a better location and allowed the port development. The results of research conducted several times had found locations that met the requirements to build a good port and could be continued to development according to the times, such as Laut Island, Kotabaru, and Batulicin which were all located on the seafront. Nevertheless, various considerations, especially the very high cost of port construction and the relatively long distance from the shipping lanes to Java, hindered the construction of a new port. The plan to build a new port was finally implemented starting in 1961. Meanwhile, the existence of Martapura port was on the skids and could no longer be maintained because the waters environment around the port was no longer supportive for its development. In 1965, with the completion of the construction of a new port located on Barito riverbanks, Martapura port began to be abandoned, even though it was still used for the sailing activities of people's boat until several years later.

\section{Conclusion}

Martapura port or the old Banjarmasin port was once prosperous in its time. The port, which is the gateway for South Kalimantan region, has supported the development of Banjarmasin and other cities in South Kalimantan, which used to be only a local economic center around Banjarmasin, such as Martapura. However, the long journey of Martapura port had to be stopped because the port waters environment was no longer able to support its development. Natural factors such as siltation in Barito estuary as the port entrance and community cultural factors with settlements on the waterway had worsened the port waters environmental conditions and finally stopped the development rate of Martapura port. 


\section{References}

1. K.R. Hall, The textile industry in Southeast Asia, 1400-1800, Journal of the Economic and Social History of the Orient 39, 2 (1996)

2. J.J. Ras, Hikayat Banjar. Translated by Siti Hawa Salleh. Kuala Lumpur: Dewan Bahasa dan Pustaka Kementerian Pendidikan Malaysia (1990)

3. Bambang Subiyakto, Pelayaran Sungai di Kalimantan Tenggara. Tinjauan Historis tentang Transportasi Air Abad XIX. Magister Thesis. Yogyakarta: Program Pascasarjana Universitas Gadjah Mada Yogyakarta (1999)

4. Endang Susilowati, Pasang Surut Pelayaran Perahu Rakyat di Pelabuhan Banjarmasin, 1880-1990. Dirsertation. Jakarta: Program Studi Ilmu Sejarah Fakultas Ilmu Pengetahuan Budaya universitas Indonesia (2004)

5. Bambang Subiyakto, Pelayaran Sungai di Kalimantan Tenggara. Tinjauan Historis tentang Transportasi Air Abad XIX. Tesis. Yogyakarta: Program Pascasarjana Universitas Gadjah Mada Yogyakarta (1999)

6. Endang Susilowati, Pelabuhan Banjarmasin 1900-1940. Profil Sebuah Pelabuhan Sungai. Kajian Sastra 26, 3 (2002)

7. $\quad$ Endang Susilowati, Pasang Surut Pelayaran Perahu Rakyat di Pelabuhan Banjarmasin, 1880-1990. Dirsertation. Jakarta: Program Studi Ilmu Sejarah Fakultas Ilmu Pengetahuan Budaya Universitas Indonesia (2004)

8. L. Gottschalk, Mengerti Sejarah. Translated by Nugroho Notosusanto. Jakarta: Yayasan Penerbit Universitas Indonesia (1975)

9. N. Herlina, Metode Sejarah. Bandung: Satya Historika (2008)

10. Arsip Nasional Republik Indonesia (ANRI), Indisch Staatsblad, 1825, no. 48.

11. R. Broersma, Handel en Bedrijf in Zuid- en Oost-Borneo. 's Gravenhage: G. Naeff (1927)

12. Ministerie van Marine (afdeling Hydrografie), Zeemansgids voor den Oost-Indischen Archipel. III. 'sGravenhage: G. Naeff (1929)

13. ANRI, Memorie van Overgave betreffende de Residentie Zuider-en Oosterafdeling van Borneo opgemaakt door den Aftredenden Resident H.J. Grijzen, 1917. Koleksi $\mathrm{MvO}$ reel 3

14. Pelabuhan Bandjarmasin Selayang Pandang, Dunia Maritim, 2 (1966)

15. M. Idwar Saleh, Lukisan Perang Banjar 1859-1865. Banjar Baru: Direktorat Jenderal Kebudayaan Departemen Pendidikan dan Kebudayaan (1982/1983)

16. H. Sjamsuddin, Pegustian dan Tumenggung. Akar Sosial, Politik, Etnis, dan Dinasti. Jakarta: Balai Pustaka (2001)

17. J.Th. Lindblad, Antara Dayak dan Belanda. Sejarah Ekonomi Kalimantan Timur dan Kalimantan Selatan 1880-1942. Translated by Ika Diyah Candra. Jakarta: Lilin Persada Press (2012)

18. J. Paulus, Encyclopaedie van Nederlandsch-Indië. Eerste deel. 'sGravenhage: Martinus Nijhoff.

19. ANRI, Memorie van Overgave betreffende de Residentie Zuider-en Oosterafdeling van Borneo opgemaakt door den Aftredenden Resident H.J. Grijzen, 1917. Koleksi $\mathrm{MvO}$ reel 3

20. Bambang Subiyakto, Pelayaran Sungai di Kalimantan Tenggara. Tinjauan Historis tentang Transportasi Air Abad XIX. Tesis. Yogyakarta: Program Pascasarjana 
Universitas Gadjah Mada Yogyakarta (1999)

21. M. Idwar Saleh, Sekilas mengenai Daerah Banjar dan Kebudayaan Sungainya sampai dengan akhir Abad-19. Banjar Baru: Direktorat Jenderal Kebudayaan Departemen Pendidikan dan Kebudayaan (1983/1984)

22. Depertement der Burgerlijke Openbare Werken, Nederlandsch-Indische Havens. Batavia (1920)

23. R. Soemedi dan Soepardi, Daerah Pelabuhan dan Daerah Kepentingan Pelabuhan Banjarmasin. Letak Geografis serta Hari Depan Pelabuhannya. Banjarmasin (1971) 